\title{
SIKAP DAN INTENSI PEMANFAATAN INTERNET DALAM KEGIATAN BISNIS
}

\author{
The Attitude and Intention of Internet Utilization for Bussines \\ Irena Anggita Nurul Adha ${ }^{*}$ dan Ratri Virianita \\ Departemen Sains Komunikasi dan Pengembangan Masyarakat, Fakultas Ekologi Manusia, IPB \\ *)Email : adhaian@gmail.com
}

Diterima 1 November 2010 / Disetujui 25 November 2010

\begin{abstract}
As developed time, needs of information and communication media become significant. Internet utilization functions for business were transformed from information exchange into an instrument for business strategy application such as marketing, selling and customer service. In general, internet has three functions in business such as communication, promotion and research. Small and middle scale entrepreneur which exposed with the growth of information technology have the options whether to utilize internet for business or not. The objective of this study is to describe attitude and intention of internet utilization for business, and to analyze the effect of attitude and subjective norm to intention of internet utilization for business on small and middle scale entrepreneur. This research used quantitative approach. The results of this study is, mostly small and middle scale entrepreneur have positive attitude and intention to internet utilization for business. Attitude and subjective norm are effected to intention to internet utilization for business.
\end{abstract}

Keywords: entrepreneur, attitude, intention and subjective norm.

\section{PENDAHULUAN}

\section{Latar Belakang}

Seiring dengan semakin pesatnya perkembangan zaman, kebutuhan manusia terhadap informasi dan media komunikasi yang mampu memenuhi hasrat keingintahuan manusia menjadi semakin besar. Internet sebagai sebuah jaringan komunikasi global memiliki beberapa fasilitas (piranti) yang dapat dimanfaatkan untuk beberapa keperluan baik dalam bisnis maupun non bisnis (Purwanto, 2003).

Usaha Kecil dan Menengah merupakan salah satu sektor ekonomi yang dapat memanfaatkan internet dalam kegiatan bisnis karena sangat diperhitungkan kontribusinya terhadap pendapatan negara. Hal tersebut dapat dilihat dari perannya dalam pertumbuhan ekonomi nasional, produk domestik bruto (PDB) yang diciptakan, nilai tambah nasional, serta penyerapan tenaga kerja. Memasuki era ekonomi global saat ini, UKM dituntut untuk dapat melakukan perubahan guna meningkatkan daya saingnya. Salah satu yang akan menentukan daya saing UKM adalah dengan penguasaan teknologi informasi (TI).

Berdasarkan sumber dari UNDP dalam Anonim (2010) penggunaan TI dapat meningkatkan transformasi bisnis melalui kecepatan, ketepatan dan efisiensi pertukaran informasi dalam jumlah yang besar. Studi kasus di Eropa juga menunjukkan bahwa lebih dari 50 persen produktivitas dicapai melalui investasi di bidang TI (Van Ark et al, dalam Anonim, 2010).
Penggunaan teknologi informasi dalam penerapannya di tingkat UKM masih menemui beberapa kendala, diantaranya adalah keterbatasan sumberdaya, baik keuangan maupun manusia. Selain itu, UKM juga belum merasakan adanya dukungan dari pemerintah, baik finansial maupun non finansial. Namun, dengan adanya tuntutan persaingan dan permintaan konsumen, pemahaman pemilik/manajer mengenai TI perlu menjadi perhatian dan faktor penggerak bagi UKM untuk mengadopsi TI. Hal tersebut sejalan dengan pendapat Riyanti (2003) bahwa berhasil atau tidaknya usaha kecil sangat bergantung pada wirausaha sebagai pemilik dan pengelola usaha kecil sehingga pemilik atau manajer saat ini dituntut untuk dapat menguasai dan memahami pemanfaatan teknologi informasi.

\section{Perumusan Masalah}

Berdasarkan uraian di atas, para pengusaha UKM yang juga mengalami paparankemajuan teknologi informasi memiliki pilihan untuk memanfaatkan internet dalamkegiatan bisnisnya. Sikap menurut Sarwono (1999) dapat menggambarkan kecenderungan untuk berperilaku, namun sikap seseorang tidak selalu berujung dengan perilaku yang sesuai dengan sikap tersebut. Berdasarkan Reasoned Actions Theory yang dikemukakan oleh Fishbein dan Ajzen dalam Azwar (1998) sikap bersamasama dengan norma subjektif akan mempengaruhi intensi atau niat untuk berperilaku. Intensi merupakan fungsi dari determinan dasar sikap dan norma subjektif. 
Berdasarkan perumusan masalah tersebut, disusunlah beberapa pertanyaan penelitian sebagai berikut:

1. Bagaimana sikap dan intensi pemanfaatan internet pada pengusaha UKM dalam kegiatan bisnis?

2. Apakah sikap dan norma subyektif berpengaruh terhadap intensi pemanfaatan internet dalam kegiatan bisnis?

\section{Tujuan Penelitian}

Adapun tujuan penelitian ini adalah untuk:

1. Mendeskripsikan sikap dan intensi pemanfaatan internet pada pengusaha UKM dalam kegiatan bisnis.

2. Menganalisis pengaruh sikap dan norma subyektif terhadap intensi pemanfaatan internet dalam kegiatan bisnis.

\section{PENDEKATAN TEORITIS}

\section{Tinjauan Pustaka}

\section{Pengusaha UKM}

Secara umum, pengusaha dapat diartikan sebagai seseorang yang bergerak dalam bidang bisnis tertentu. Wiraswasta menurut Saputro (2009) adalah suatu sikap mental yang berani menanggung resiko, berpikiran maju, berani berdiri di atas kaki sendiri.

Definisi lain mengenai wirausahawan dikemukakan oleh Zimmer dalam Saputro (2009) yang menyatakan bahwa wirausaha adalah orang yang menciptakan bisnis baru dengan mengambil resiko dan ketidakpastian demi mencapai keuntungan dan pertumbuhan dengan cara mengidentifikasi peluang dan menggabungkan sumberdaya yang diperlukan untuk mendirikannya.

Usaha kecil menurut Pasal 1 Undang-Undang No.9 Tahun 1995 dalam Riyanti (2003) didefinisikan sebagai kegiatan ekonomi rakyat yang berdiri sendiri, bukan merupakan anak atau cabang perusahaan yang dimiliki, dikuasai atau berafiliasi dengan usaha menengah atau usaha besar, serta berbentuk usaha perseorangan, atau badan usaha yang tidak berbadan hukum, termasuk koperasi. UndangUndang No.20 Tahun 2008 juga mendefinisikan usaha kecil sebagai entitas yang memiliki kriteria omzet per tahun sebagai berikut: (1). Kekayaan bersih lebih dari Rp. 50.000.000,- (lima puluh juta rupiah) sampai dengan Rp. 500.000.000,- (lima ratus juta rupiah) tidak termasuk tanah dan bangunan tempat usaha; dan (2). Memiliki hasil penjualan tahunan lebih dari Rp. 300.000.000,- (tiga ratus juta rupiah) sampai dengan paling banyak Rp. 2.500.000.000,- (dua milyar lima ratus juta rupiah). Usaha menengah adalah entitas usaha yang memiliki kriteria: (1). Kekayaan bersih lebih dari Rp. 500.000.000,- (lima ratus juta rupiah) sampai dengan paling banyak $\mathrm{Rp}$. 10.000.000.000,- (sepuluh milyar rupiah) tidak termasuk tanah dan bangunan tempat usaha; dan (2). Memiliki hasil penjualan tahunan lebih dari Rp. 2.500.000.000,- (dua milyar lima ratus ribu rupiah) sampai dengan paling banyak Rp. 50.000.000.000,- (lima puluh milyar rupiah).

Berdasarkan berbagai definisi dan konsep di atas, wirausahawan atau pengusaha UKM dalam konteks penelitian ini, merupakan seseorang yang mengusahakan sumberdaya yang ada di sekitarnya menjadi suatu peluang bisnis tertentu dan mengelola sumberdaya tersebut sehingga menjadi sesuatu dengan nilai tambah yang lebih tinggi untuk mendapatkan keuntungan tertentu. Definisi ini hanya berlaku bagi mereka yang mengelola dan memiliki usaha sendiri serta mempekerjakan orang lain dalam menjalankan usahanya. Wirausaha atau pengusaha yang dimaksud adalah seseorang yang mempunyai tanggung jawab penuh dan langsung atas unit usaha yang dijalankannya.

Selain itu, dengan mengacu pada pengertian usaha kecil menurut Undang-Undang No.20 Tahun 2008, maka penelitian ini difokuskan kepada pengusaha dengan skala kecil dan menengah dengan omzet Rp. 50.000.000,- (lima puluh juta rupiah) sampai dengan Rp. 50.000.000.000,(lima puluh miliar rupiah).

\section{Teori Sikap tentang Hubungan Sikap dengan Perilaku}

Sikap telah menjadi konsep utama dalam psikologi sosial dalam perkembangannya (Allport dalam Baron \& Byrne, 2003). Sikap seringkali dipandang sebagai salah satu faktor yang mempengaruhi perilaku. Para ahli telah mengemukakan begitu banyak teori dan konsep mengenai sikap dan pembentukannya serta hubungan antara sikap dengan perilaku. Penelitian ini memfokuskan pada Theory of Reasoned Action yang dikemukakan oleh Fishbein dan Ajzen sebagai dasar dalam menguji hubungan antara sikap dan intensi dengan pemanfaatan internet pada pengusaha UKM dalam kegiatan bisnis.

Berdasarkan Gambar 1., Theory of Reasoned Action yang dikemukakan oleh Fishbein dan Ajzen dalam Sarwono (1999) memandang bahwa sikap dapat mempengaruhi perilaku lewat suatu proses pengambilan keputusan yang teliti dan beralasan, dan dampaknya terbatas hanya pada tiga hal, yaitu: (1) perilaku tidak banyak ditentukan oleh sikap umum tertapi oleh sikap yang spesifik terhadap sesuatu; (2) perilaku tidak hanya dipengaruhi oleh sikap tetapi juga oleh norma-norma subjektif (subjective norms) yaitu keyakinan kita mengenai apa yang orang lain inginkan agar kita perbuat; (3) sikap terhadap suatu perilaku bersama-sama dengan norma subjektif membentuk suatu intensi atau niat untuk berperilaku tertentu.

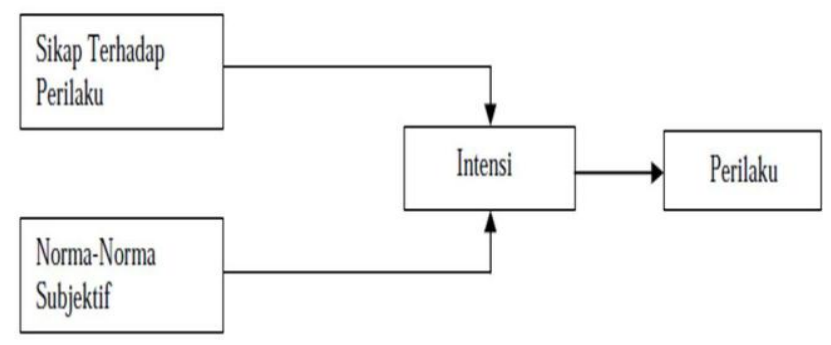

\section{Gambar 1. Teori Tindakan Beralasan}

Sumber: Fishbein dan Ajzen (1980) dalam Azwar (1998)

Intensi merupakan fungsi dari dua determinan dasar, yaitu sikap individu terhadap perilaku (aspek personal) dan persepsi individu terhadap tekanan sosial untuk melakukan atau tidak melakukan perilaku yang bersangkutan yang disebut dengan norma subjektif (Azwar, 1998). Intensi atau niat untuk berperilaku akan 
muncul sebagai akibat dari adanya sikap terhadap perilaku tertentu yang cenderung positif serta norma subjektif.

Intensi menurut Sujanto, Lubis dan Hadi (2004) digunakan dalam arti yang meliputi pengertian: harapanharapan, keinginan-keinginan, ambisi, cita-cita, dan rencana-rencana seseorang. Secara sederhana intensi dapat diartikan sebagai niat untuk berperilaku (Azwar, 1998). Norma subjektif menurut Baron dan Byrne (2003) adalah keyakinan individu mengenai persepsi apakah orang lain akan menyetujui atau menolak tingkah laku tersebut. Selanjutnya, intensi yang telah dimiliki oleh individu tersebut akan menjadi dasar pada perilaku yang dimunculkannya. Sikap dinilai dapat digunakan sebagai alat untuk memprediksi perilaku. Namun, sikap yang dinyatakan oleh seseorang tidak selalu sesuai dengan perilaku yang terlihat. Sikap seringkali tidak dapat secara langsung mempengaruhi perilaku. Tindakan atau perilaku yang muncul pada seseorang didahului oleh niat untuk berperilaku (intensi). Berdasarkan teori reasoned actions intensi pada gilirannya dipengaruhi oleh dua faktor, yaitu sikap terhadap tingkah laku dan norma subjektif.

\section{Sikap terhadap Pemanfaatan Internet dalam Kegiatan Bisnis}

Sikap secara umum diartikan sebagai suatu kecenderungan yang dimilliki oleh individu ataupun kelompok untuk berperilaku. Sikap dapat berupa kecenderungan yang positif maupun negatif. Myers dalam Sarwono (1999) mendefinisikan sikap sebagai "attitude is a favorable or unfavorable evaluative reaction to ward something or someone, exhibited in one's belief, feelings or intended behavior". Definisi tersebut senada dengan definisi sikap yang dikemukakan oleh Ajzen dalam Sarwono (1999), yaitu: "an attitude is a disposition to respond favorably or unfavorably to an object, person, institution or event". Baron dan Byrne (2003) juga mendefinisikan sikap sebagai evaluasi terhadap berbagai aspek dalam dunia sosial serta bagaimana evaluasi tersebut memunculkan rasa suka atau tidak suka terhadap isu, ide, orang, kelompok sosial, objek, bahkan makanan penutup. Dari sekian banyak definisi mengenai sikap tersebut secara keseluruhan semuanya mengemukakan adanya kesamaan pendapat mengenai konsep sikap, yaitu adanya ciri khas: (1) mempunyai objek tertentu (orang, perilaku, konsep, situasi, benda dan sebagainya) dan (2) mengandung penilaian (setuju-tidak setuju, sukatidak suka) sebagaimana diungkapkan oleh Bem et.al dalam Sarwono (1999).

Berdasarkan semua pengertian dan definisi di atas, dan merujuk pada kesimpulan Sarwono (1999) mengenai definisi sikap maka sikap merupakan suatu kecenderungan berperilaku terhadap suatu objek tertentu yang menunjukkan rasa suka dan rasa tidak suka, setuju dan tidak setuju serta mengandung tiga komponen yang mengorganisasikan sikap individu tersebut, yaitu:

\section{Kognitif}

Komponen kognitif terdiri dari pemikiran seseorang mengenai objek tertentu, seperti fakta, pengetahuan dan keyakinan. Sarwono (1999) mengungkapkan bahwa komponen kognitif merupakan komponen pengetahuan atau kesadaran akan suatu objek sikap tertentu.

\section{Afektif}

Komponen afektif terdiri dari perasaan positif atau negatif yang diasosiasikan dengan objek sikap. Baron dan Byrne (2003) mendefinisikan afeksi sebagai perasaan dan suasana hati yang dirasakan oleh seseorang. Rakhmat (2008) juga mengemukakan bahwa afeksi berhubungan dengan emosi, perasaan dan sikap. Komponen afektif meliputi bagaimana faktor emosi dan perasaan individu mempengaruhi sikap.

\section{Konatif}

Komponen konatif merupakan tendensi untuk melakukan tindakan tertentu berkaitan dengan objek sikap. Azwar (1998) mendefinisikan konasi sebagai komponen sikap yang menunjukkan bagaimana kecenderungan perilaku yang terdapat dalam diri seseorang.

Ketiga komponen tersebut mengorganisasikan sikap secara bersamaan. Azwar (1998) mengemukakan bahwa inferensi atau penyimpulan tentang sikap harus didasarkan pada suatu fenomena yang diamati atau diukur. Fokus dalam penelitian ini, fenomena yang akan diamati adalah mengenai pemanfaatan internet pada pengusaha UKM dalam kegiatan bisnis. Azwar (1998) mengemukakan bahwa apabila salah satu saja di antara ketiga komponen sikap terebut tidak konsisten satu sama lain, maka akan terjadi ketidakselarasan yang menyebabkan timbulnya mekanisme perubahan sikap hingga konsistensi tersebut kembali tercapai. Sikap individu muncul akibat adanya proses tertentu yang bisa muncul dari dalam dan luar lingkungannya.

\section{Kerangka Pemikiran}

Berdasarkan Theory of Reasoned Actions yang dikemukakan oleh Fishbein dan Ajzen dalam Azwar (1998) intensi merupakan fungsi dari dua determinan dasar, yaitu sikap individu terhadap perilaku (aspek personal) dan persepsi individu terhadap tekanan sosial untuk melakukan atau tidak melakukan perilaku yang bersangkutan yang disebut dengan norma subjektif. Intensi atau niat untuk berperilaku akan muncul sebagai akibat dari adanya sikap terhadap perilaku tertentu yang cenderung positif serta norma subjektif.

Sikap itu sendiri terdiri atas komponen-komponen yang mengorganisasikan sikap secara keseluruhan, yaitu: komponen kognitif berupa pengetahuan dan kepercayaan individu terhadap objek sikap; komponen afektif berupa perasaan dan emosi individu terhadap objek sikap, dan; komponen konatif berupa kecenderungan individu untuk berperilaku.

Norma subjektif merupakan keyakinan individu mengenai apa yang orang lain inginkan agar ia perbuat (Sarwono, 1999). Sikap terhadap pemanfaatan internet dalam kegiatan bisnis bersama-sama dengan norma subjektif merupakan determinan dasar dari intensi atau niat yang akhirnya berhubungan dengan pemanfaatan internet dalam kegiatan bisnis. 


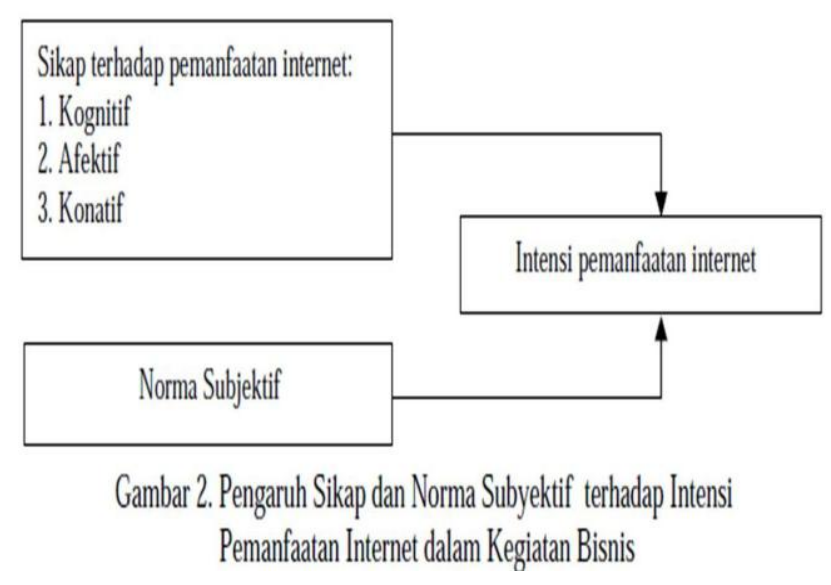

Hipotesis Penelitian

Berdasarkan kerangka pemikiran di atas, maka hipotesis penelitian adalah sebagai berikut:

1. Sikap terhadap pemanfaatan internet memiliki hubungan dengan intensi pemanfaatan internet pada pengusaha UKM dalam kegiatan bisnis.

2. Norma subjektif memiliki hubungan dengan intensi pemanfaatan internet pada pengusaha UKM dalam kegiatan bisnis.

3. Sikap dan Norma subyektif mempengaruhi intensi pemanfaatan internet pada peungusaha UKM dalam kegiatan bisnis.

\section{PENDEKATAN LAPANG}

\section{Metode Penelitian}

Penelitian ini merupakan penelitian survai dengan tipe eksplanatory atau confirmatory research. Penelitian explanatory merupakan penelitian penjelasan yang menyoroti hubungan antar variabel-variabel penelitian dan menguji hipotesis yang telah dirumuskan sebelumnya (Singarimbun, 1989). Pendekatan yang dilakukan dalam penelitian ini adalah pendekatan kuantitatif. Pendekatan kuantitatif digunakan untuk mencari informasi faktual secara detail tentang hal-hal yang sedang menggejala dan mengidentifikasi masalah-masalah atau untuk mendapatkan justifikasi keadaan dan kegiatan-kegiatan yang sedang berjalan (Wahyuni, 2004).

\section{Teknik Penentuan Responden}

Populasi studi ini mencakup wirausahawan yang memiliki usaha skala kecil dan menengah berdasarkan kriteria usaha kecil menurut Undang-Undang No.9 Tahun 1995 yaitu kegiatan ekonomi rakyat yang berdiri sendiri, bukan merupakan anak atau cabang yang dimiliki, dikuasai atau berafiliasi dengan usaha menengah dan usaha besar, serta berbentuk usaha perseorangan atau badan usaha yang tidak berbadan hukum, termasuk koperasi dan UndangUndang. No. 20 tahun 2008. Responden merupakan wirausahawan yang memiliki usaha kecil maupun usaha menengah yang terdaftar sebagai UKM binaan Unit Pelayanan dan Pendampingan Usaha Kecil (UPP-UKM) LPPM IPB.

Teknik pengambilan sampel dilakukan secara purposive. Penentuan jumlah responden ini disesuaikan dengan daftar jumlah pengusaha UKM binaan LPPM IPB yang kemudian dipilih secara sengaja untuk mewakili tiap-tiap kelompok bidang usaha yang dibina oleh UPP-UKM LPPM IPB. Populasi dalam penelitian ini berjumlah 166 pengusaha UKM yang berada di bawah binaan UPPUKM LPPM IPB. Jumlah sampel yang diambil dalam penelitian ini adalah sebanyak 40 responden agar hasil penelitian dapat lebih representatif.

\section{Teknik Pengumpulan Data}

Data yang digunakan dalam penelitian ini adalah data primer dan data sekunder. Pengumpulan data primer dilakukan melalui wawancara terstruktur dengan menggunakan metode survai dan pengamatan terhadap usaha yang dimiliki responden untuk mengamati penggunaan dan pemanfaatan internet dalam kegiatan bisnisnya. Instrumen yang digunakan untuk mengumpulkan data kuantitatif adalah kuesioner. Kuesioner digunakan untuk memperoleh data mengenai karakteristik responden, sikap, norma subjektif dan intensi. Sikap, norma subjektif dan intensi pengusaha UKM diukur dengan menggunakan skala likert dengan respon jawaban berupa sangat tidak setuju, tidak setuju, netral, setuju dan sangat setuju. Data sekunder diperoleh dari studi literatur dan dokumen yang dimiliki oleh UPPUKM LPPM IPB mengenai profil UKM-UKM binaan UPP-UKM LPPM IPB.

\section{Pengolahan dan Analisis Data}

Data yang diperoleh dianalisis secara kuantitatif dengan menggunakan kuesioner. Pengolahan data dilakukan dengan terlebih dahulu melakukan pemberian skor pada masing-masing jawaban responden. Pemberian skor untuk masing-masing jawaban responden pada pertanyaan mengenai sikap, norma subjektif dan intensi pemanfaatan internet adalah: 1). Sangat tidak setuju; 2). Tidak setuju; 3). Netral; 4). Setuju; 5). Sangat setuju. Tahap selanjutnya adalah perhitungan persentase skor responden yang dibuat dalam bentuk tabulasi silang dan dianalisis secara deskriptif. Data yang dikumpulkan selanjutnya diolah secara statistik dengan mengunakan software SPSS for Windows 17.0. Uji Regresi digunakan untuk melihat hubungan dan pengaruh sikap dan norma subjektif terhadap intensi pemanfaatan internet.

\section{Waktu dan Tempat Penelitian}

Penentuan tempat dilatarbelakangi tujuan penelitian ini, yaitu mendeskripsikan sikap dan intensi pemanfaatan internet pada pengusaha UKM dalam kegiatan bisnis; dan menganalisis pengaruh sikap dan norma subjektif terhadap intensi pemanfaatan internet pada pengusaha UKM dalam kegiatan bisnis. Berdasarkan tujuan tersebut, maka dipilihlah UKM binaan UPP-UKM LPPM IPB sebagai tempat penelitian dengan pertimbangan sebagai berikut:

1. UPP-UKM LPPM IPB merupakan salah satu lembaga dalam lingkup IPB yang memberikan perhatiannya pada pengembangan UKM-UKM terutama di lingkungan kampus IPB.

2. Belum adanya penelitian mengenai bagaimana sikap pengusaha UKM terhadap pemanfaatan internet dalam kegiatan bisnis yang dilakukan pada unit-unit UKM binaan UPP-UKM LPPM IPB tersebut. 
Dengan dipilihnya lokasi ini dapat mendukung kebutuhan data tentang sikap dan intensi pemanfaatan internet pada pengusaha UKM dalam kegiatan bisnis. Penelitian dilaksanakan pada bulan Juli 2010. Pengolahan data dan hasil penulisan laporan dilakukan pada bulan bulan JuliSeptember 2010.

\section{PROFIL USAHA KECIL DAN MENENGAH BINAAN UPP-UKM LPPM IPB}

Pada Tabel 1 terlihat bahwa UKM yang paling banyak bergabung dengan UPPUKM LPPM IPB adalah UKM pada bidang perdagangan, yaitu sebanyak 64 unit usaha atau 39 persen dari total keseluruhan. Bidang usaha yang paling sedikit bergabung dengan UPP-UKM LPPM IPB adalah bidang perdagangan dan home industry dengan hanya sembilan unit UKM atau lima persen dari total keseluruhan UKM binaan UPP-UKM LPPM IPB.

Bidang perdagangan dan home industry ternyata masih sangat sedikit dilirik oleh para pengusaha UKM sebagai sebuah bidang usaha yang menjanjikan.

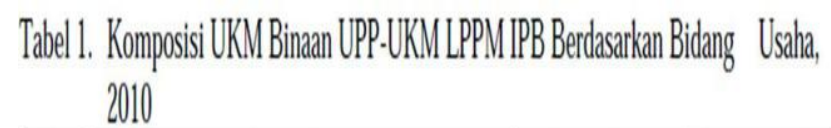

\begin{tabular}{|c|c|c|c|}
\hline No. & Bildang Lishta & Jumbah (win) & Pessentsece \\
\hline l. & $\begin{array}{l}\text { Jax boga dan pentualana anda makanana dan } \\
\text { minuman }\end{array}$ & 25 & 15 \\
\hline 2 & 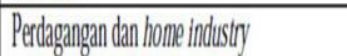 & 9 & 5 \\
\hline 3 & Perdagangan & 64 & 39 \\
\hline 4. & ase & 33 & 20 \\
\hline \multirow[t]{2}{*}{5.} & Perklkanan, pertanlan dan peternakan & 35 & 21 \\
\hline & Toal & 166 & 100 \\
\hline
\end{tabular}

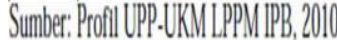

Bidang usaha para UKM yang menjadi binaan UPP-UKM LPPM IPB secara keseluruhan dibagi ke dalam lima bidang usaha, yaitu: (1). Bidang jasa boga dan penjualan aneka makanan dan minuman meliputi catering, rumah makan, kantin, warung makan, penjualan aneka makanan ringan dan kue, aneka masakan dan minuman, coklat; (2). Bidang perdagangan dan home industry meliputi aneka kerajinan handycraft, bunga kering, bunga plastik, souvenir, sendal dan tas; (3). Bidang perdagangan meliputi usaha sembako, tanaman hias, sayuran, aneka olahan ikan/daging sapi/ayam, alat elektronik dan logam, bahan bangunan, suku cadang, pakaian, kosmetik dan obat-obatan serta mainan; (4). Bidang jasa meliputi salon dan rias pengantin, bengkel dan tambal ban, digital print dan fotografi, pembuatan kusen, sewa kost dan rental; (5). Bidang perikanan, pertanian dan peternakan.

Di antara lima bidang usaha yang dikemukakan di atas, berikut ini profil Usaha Kecil dan Menengah Binaan UPP-UKM LPPM IPB yang menjadi sampel penelitian.

\section{Kansas Fried Chicken}

Kansas Fried Chicken mulai dirintis sejak awal tahun 2006. Usaha ini merupakan salah satu bagian dari usaha
CV. Mandiri Citra Lestari yang dimiliki oleh Ir. Emet Suhemat. Peusahaan ini telah memiliki rumah pemotongan ayam (RPA) sendiri yang telah beroperasi sejak tahun 2003 dan telah bekerjasama dengan perusahaan-perusahaan besar ternak ayam seperti PT. Sierad, PT. Charoen Prophand, PT. Samsung dan PT.

Malindo. Saat ini, outlet-outlet yang telah dibuka masih terkonsentrasi di wilayah sekitar Bogor. Dalam upaya pengembangan usahanya, Kansas Fried Chicken menerapkan sistem franchise.

\section{Rindu Jaya/Tirta Wangi}

Peusahaan Rindu Jaya/Tirta Wangi bergerak dalam bidang agribisnis, khususnya usaha pemancingan. Pemancingan Rindu Jaya/Tirtawangi dimiliki oleh Bapak Gondol Sugito. Adapun lokasi pemancingan terletak di Jalan Raya Parung-Bogor, Kampung Lebak Wangi RT. 02/02, Desa Pemagarsari.

\section{Kantin Fahutan ASIK}

Kantin Fahutan ASIK dikelola oleh Ibu Lindia SM dan Bapak Chamim Mashar. Kantin terletak di sebelah kantor BEM-E Fakultas Kehutanan Institut Pertanian Bogor. Pelayanan yang ditawarkan oleh Kantin Fahutan ASIK adalah penyediaan berbagai makanan dan minuman yang bersih, sehat dan nyaman serta harga yang terjangkau terutama bagi mahasiswa. Pengelola Kantin Fahutan ASIK juga menawarkan paket snack dalam kotak yang dapat dipesan untuk berbagai keperluan.

\section{Mutiara Tugu Ibu}

Mutiara Tugu Ibu didirikan pada tanggal 16 Mei 2005, dengan pemilik bernama Drs. H. Suhaibin Sidi, MBA. Madu Mutiara Tugu Ibu merupakan salah satu perusahaan dengan komoditi berbasis produk asal lebah madu. Selain memproduksi madu murni alami maupun produk sampingan madu seperti royal jelly, propolis, bee polen, bee wax dan bee venom, perusahaan Mutiara Tugu Ibu juga memproduksi produk kecantikan berbahan dasar madu seperti sabun madu transparan, sabun madu cair, shampo madu dan cream madu.

Pusat produksi berlangsung di Jalan Raya Bogor Km. 33,5 No. 105, Curug, Cimanggis, Depok. Sejak awal didirikan, produk Mutiara Tugu Ibu telah terdaftar di Dinas Kesehatan Depok dan telah memiliki sertifikat halal. Keaslian madu dan kualitas produk yang dihasilkan oleh perusahaan Mutiara Tugu Ibu telah dijamin, karena memiliki peternakan lebah sendiri sehingga bunga, rasa dan aroma dapat dikontrol dengan ketat oleh perusahaan.

\section{Widyasari}

Widyasari merupakan perusahaan yang namanya diambil dari nama pemilik perusahaan ini, yaitu Ibu Restu Widyasari. Widyasari memproduksi produk aromatherapy dan spa material yang mulai dirintis sejak 3 Januari 2009. Perusahaan Widyasari terletak di Jalan Raya Darmaga Km. 7 No. 73 Komplek HE Suradi RT 03/02, Bogor Barat. Produk aromatherapy dan spa material yang diproduksi oleh Widyasari terlebih dahulu diuji di laboratorium Teknik Industri Institut Pertanian Bogor. Produk Widyasari diantaranya adalah machan (eye anti wringle oil) yang berfungsi untuk mengurangi 
kerutan di sekitar mata, anglo, minyak esensial dan lilin, lulur tradisional (lulur teh hijau, lulur kopi, lulur coklat, lulur bengkuang, lulur kemuning dan lulur daun jeruk), minyak muka (face oil), minyak pijat, rempah mandi, garam mandi/kaki, bedak dingin dan minyak rambut.

\section{Green Co IPB Souvenirs Centre}

Usaha ini terletak di kawasan pertokoan Grawida, tepatnya di Jalan Babakan raya Kompleks Pertokoan Grawida Kampus IPB Darmaga. Usaha ini merupakan usaha pertama yang dimiliki oleh KOPMA (Koperasi Mahasiswa) IPB yang berdiri pada tahun 2001. Green Co menyediakan berbagai aksesoris IPB mulai dari souvenir dan berbagai aksesoris IPB seperti stiker, $t$-shirt, sweater, payung, pulpen, pin, mug, jas lab, gantungan kunci, jam, kancing almamater dan sebagainya. Slogan yang diusung oleh oleh Green Co adalah "Membuat anda Bangga dengan IPB". Produk yang dijual di Green Co sebagian diproduksi sendiri dan sebagian lagi bekerjasama dengan supplier dari anggota KOPMA maupun non-anggota.

\section{KARAKTERISTIK PENGUSAHA UKM BINAAN UPP-UKM LPPM IPB}

Karakteristik pengusaha UKM binaan UPP-UKM LPPM IPB yang menjadi responden dalam penelitian ini dilihat dari usia, jenis kelamin, tingkat pendidikan, suku bangsa dan bidang usaha.

\section{Usia}

Karakteristik usia responden dalam penelitian ini dibagi ke dalam tiga kategori usia menurut Hurlock (1991) mengenai usia perkembangan karir individu, yaitu 18-40 tahun atau masa dewasa awal, 41-60 tahun atau masa dewasa madya, dan >60 tahun atau masa dewasa akhir.

Tabel 2 memperlihatkan bahwa sebanyak 20 orang atau 50 persen responden berada pada usia masa dewasa awal. Masa dewasa awal erat kaitannya dengan tugas perkembangan dalam hal membentuk keluarga dan pekerjaan. Pada rentang usia ini, seseorang cenderung mulai membentuk dan membangun karir dan usahanya termasuk dalam memulai usaha tertentu. Hanya ada dua orang atau lima persen responden pada usia dewasa akhir atau >60 tahun. Pada rentang usia ini Hurlock (1991) mengemukakan bahwa seseorang mulai mengurangi kegiatan karirnya atau berhenti sama sekali. Pada masa ini, karir seseorang juga dianggap sebagai masa pensiun sehingga waktunya lebih banyak dihabiskan untuk menikmati hari tua dibandingkan dengan mengelola suatu bisnis tertentu.

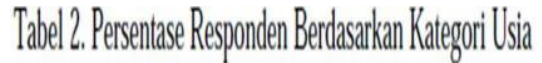

\begin{tabular}{|c|c|c|}
\hline Kategoor Lsia & Frekuens: & Persentase $(\%)$ \\
\hline 18.40 tahun & 20 & 50 \\
\hline 41.60 tahun & 18 & 45 \\
\hline sol tatun & 2 & 5 \\
\hline Total & 40 & 100 \\
\hline
\end{tabular}

Jenis Kelamin
Pengusaha UKM binaan UPP-UKM LPPM IPB terdiri dari 22 responden lakilaki dan 18 responden perempuan. Tabel 3 memperlihatkan bahwa jumlah atau persentase responden laki-laki dan perempuan relatif seimbang. Persentase responden berjenis kelamin perempuan yang cukup besar, yaitu 45 persen, menunjukkan perempuan telah banyak berkecimpung dalam mengelola bidang usaha tertentu terutama pada sektor informal

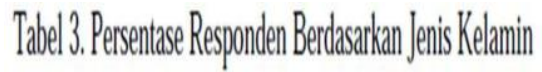

\begin{tabular}{|c|c|c|}
\hline Jents Kelanin & Frethersis & Persentise $\left(P_{0}\right)$ \\
\hline Lakx:Lakl & 2 & 55 \\
\hline 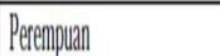 & 18 & 45 \\
\hline Toal] & 40 & 100 \\
\hline
\end{tabular}

\section{Tingkat Pendidikan}

Sebagian besar pengusaha UKM yang tergabung dalam UKM binaan UPP-UKM LPPM IPB tergolong berpendidikan tinggi. Tabel 4 memperlihatkan bahwa 82,5 persen responden adalah lulusan Akademi/Perguruan Tinggi. Hal ini disebabkan sebagian dari UKM binaan UPP-UKM LPPM IPB terdiri dari UKM paguyuban pensiunan IPB dan UKM wirausaha muda (mahasiswa S1, S2 dan alumni IPB). Adapun tingkat pendidikan terendah responden adalah Tamat SMP/Sederajat, yaitu sebesar 7,5 persen.

\begin{tabular}{|c|c|c|}
\hline Tingkat Pendddkan & Frekuensi & Persentlase $(\%)$ \\
\hline Tamat SUP/S Secterajat & 3 & 7,5 \\
\hline Tamat SMA S Sederajat & 4 & 10 \\
\hline Tamat Akadem|Perguruan "Iingeg & 33 & 82,5 \\
\hline Total & 40 & 100 \\
\hline
\end{tabular}

\section{Suku Bangsa}

Karakteristik suku bangsa dalam penelitian ini dikategorikan dalam enam suku bangsa. Keenam suku bangsa tersebut didasarkan atas pendapat Geertz (1981) bahwa beberapa suku di Indonesia terkenal dengan kelihaiannya dalam berdagang. Orang-orang Suku Bugis dan Banjar rata-rata memiliki pekerjaan berdagang, begitu pula dengan Etnis Tionghoa. Sektor dagang di Indonesia sejak dahulu banyak dikuasai oleh orang-orang Etnis Cina, Arab dan India. Selain itu, Suku Minangkabau dan Batak merupakan suku bangsa yang berorientasi dagang. Hasil penelitian ini tidak menemukan responden dengan suku Arab, Batak dan Cina/Tionghoa, kemungkinan karena lokasi penelitian berada di wilayah yang mayoritas penduduknya bersuku Sunda. 


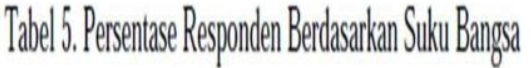

\begin{tabular}{|c|c|c|}
\hline Suku Bangsa & Freterens & 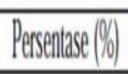 \\
\hline \begin{tabular}{|l|} 
Jalla \\
\end{tabular} & 17 & 42,5 \\
\hline Minang & 4 & 10 \\
\hline Sunda & 19 & 47,5 \\
\hline Total & 40 & 100 \\
\hline
\end{tabular}

Tabel 5 memperlihatkan bahwa responden penelitian ini paling banyak berasal dari suku Sunda, yaitu 19 orang atau 47,5 persen. Angka ini relatif seimbang dengan responden suku Jawa, yaitu 17 orang atau 42,5 persen, sebagai penduduk pendatang. Hal ini menunjukkan karakteristik pendatang yang pada umumnya cenderung lebih ulet, motivasi tinggi, dan kemauan kuat dalam berusaha sebagai strategi mempertahankan hidup di perantauan.

\section{Bidang Usaha}

Sebagian besar reponden, yaitu 30 persen, adalah pemilik usaha bidang jasa boga dan penjualan aneka makanan dan minuman yang terdiri dari pemilik usaha warung makan, kantin, catering dan pembuatan makanan kecil basah maupun kering.

\section{Tabel 6. Persentase Responden Berdasarkan Bidang Usaha}

\begin{tabular}{|c|c|c|c|}
\hline No. & Bildang Usaha & Jumlah (unit) & Persentase $(\%)$ \\
\hline 1. & $\begin{array}{l}\text { Jas boga dan penjualan anekka makanan dan } \\
\text { minuman }\end{array}$ & 12 & 30 \\
\hline 2 . & Perchagangan dan home industry & 5 & 12,5 \\
\hline 3. & Perdagangan & 5 & 12,5 \\
\hline 4. & Jasa & 9 & 22,5 \\
\hline 5. & Perklkanan, pertanlan dan peternakan & 9 & 22,5 \\
\hline & Total & 40 & 100 \\
\hline
\end{tabular}

\section{SIKAP PENGUSAHA UKM TERHADAP PEMANFAATAN INTERNET DALAM KEGIATAN BISNIS}

Sikap secara umum diartikan sebagai suatu kecenderungan yang dimilliki oleh individu ataupun kelompok untuk berperilaku. Sikap dapat berupa kecenderungan yang positif maupun negatif. Sikap terhadap pemanfaatan internet dalam konteks penelitian ini adalah kecenderungan berperilaku yang menunjukkan rasa suka atau tidak suka, setuju atau tidak setuju terhadap pemanfaatan internet. Pengukuran terhadap sikap dapat dilihat melalui pernyataan-pernyataan yang mengandung tiga komponen sikap, yaitu kognitif, afektif dan konatif. Setiap komponen sikap dibagi ke dalam dua tingkatan, yaitu sikap positif dan sikap negatif. Nilai positif dan negatif diketahui dengan melakukan statistika deskriptif terhadap respon responden terhadap alat ukur berupa skala Likert.
Tabel7. Persentase Sikap Pengusaha UKM terhadap Pemanfaatan Internet dalam Kegiatan Bisnis

\begin{tabular}{|l|c|c|c|c|}
\hline \multirow{2}{*}{ Sikap } & \multicolumn{2}{|c|}{ Positif } & \multicolumn{2}{c|}{ Negatif } \\
\cline { 2 - 5 } & $n$ & $\%$ & $n$ & $\%$ \\
\hline Kognitiff & 25 & 62,5 & 15 & 37,5 \\
\hline Afektif & 23 & 57,5 & 17 & 42,5 \\
\hline Konatif & 26 & 65 & 14 & 35 \\
\hline Sikap & 25 & 62,5 & 15 & 37,5 \\
\hline
\end{tabular}

Tabel 7 memperlihatkan bahwa sebagian besar responden, yaitu 62,5 persen, memiliki sikap yang positif terhadap pemanfaatan internet dalam kegiatan bisnis. Tabel ini juga memperlihatkan ketiga komponen pembentuk sikap, yaitu kogintif, afektif dan konatif, pada responden juga positif. Hal ini menunjukkan keyakinan, kesukaan dan kecenderungan yang positif terhadap penggunaan internet dalam kegiatan bisnis karena dianggap dapat membantu komunikasi dengan pelanggan atau rekan bisnis, membantu untuk memperoleh informasi tentang produk dan pasar, dan membantu untuk melakukan kegiatan promosi produk dan perusahaan.

Terlihat pada Tabel 7 bahwa sebagian besar responden $(62,5 \%)$ memiliki kognisi yang positif terhadap pemanfaatan internet dalam kegiatan bisnis. Hal ini menunjukkan bahwa sebagian besar responden telah memiliki pengetahuan dan sadar tentang manfaat internet dalam kegiatan bisnis, baik dalam fungsi komunikasi, promosi dan riset.

Kesadaran dan pengetahuan tersebut muncul sebagai hasil dari proses interaksi responden dengan lingkungannya. Hal tersebut juga didukung oleh informasi yang diterima para pengusaha binaan UPP-UKM mengenai kemudahan proses komunikasi, promosi dan riset dengan menggunakan media internet dari Ketua Paguyuban UKM binaan UPP-UKM LPPM IPB.

Tabel 7 memperlihatkan bahwa sebagian besar responden $(57,5 \%)$ memiliki afeksi yang positif terhadap pemanfaatan internet dalam kegiatan bisnis, baik dalam fungsi komunikasi, promosi dan riset. Kesukaan tersebut muncul kemungkinan karena pengusaha UKM sudah mengetahui terlebih dahulu manfaat yang akan didapatkan dalam penggunaan internet. Akan tetapi, tampak bahwa 42,5 persen responden memiliki afeksi negatif terhadap pemanfaatan internet yang mungkin disebabkan oleh anggapan bahwa pemanfaatan internet memerlukan keterampilan dan penguasaan teknologi informasi yang memadai sehingga menimbulkan ketidaksukaan terhadap penggunaannya.

Sebagian besar responden (65\%) memiliki konasi yang positif terhadap pemanfaatan internet dalam kegiatan bisnis. Angka ini menunjukkan bahwa sebagian responden memiliki kecenderungan untuk memanfaatkan internet dalam menjalankan bisnisnya. Hal ini dapat disebabkan oleh pengetahuan dan kesadaran responden tentang manfaat penggunaan internet dan juga ketertarikan responden dalam penggunaannya sebagai 
sarana komunikasi, promosi dan riset untuk menjalakan usahanya.

\section{INTENSI PEMANFAATAN INTERNET DALAM KEGIATAN BISNIS PADA PENGUSAHA UKM BINAAN UPP-UKM LPPM IPB}

Berdasarkan Theory of Reasoned Actions yang dikemukakan oleh Fishbein dan Ajzen dalam Azwar (1998) Intensi merupakan fungsi dari dua determinan dasar, yaitu sikap individu terhadap perilaku (aspek personal) dan persepsi individu terhadap tekanan sosial untuk melakukan atau tidak melakukan perilaku yang bersangkutan yang disebut dengan norma subjektif. Intensi atau niat untuk berperilaku akan muncul sebagai akibat dari adanya sikap terhadap perilaku tertentu yang cenderung positif dan norma subjektif.

Intensi adalah niat untuk berperilaku. Intensi dalam konteks penelitian ini adalah niat untuk memanfaatkan internet dalam kegiatan bisnis. Intensi dapat diukur melalui pernyataan-pernyataan yang menggambarkan niat untuk memanfaatkan internet dalam kegiatan bisnis.

\section{Tabel 8. Persentase Intensi Pemanffatatan Internet dalam Kegiatan Bisnis pada Pengussha} UKM

\begin{tabular}{|c|c|c|}
\hline \multicolumn{1}{|c|}{ Intensi } & Frekuensi & Persentase $(\%)$ \\
\hline Positif & 22 & 55 \\
\hline Negatif & 18 & 45 \\
\hline \multicolumn{1}{|c|}{ Total } & 40 & 100 \\
\hline
\end{tabular}

Terlihat pada Tabel 8 bahwa intensi atau niat responden untuk memanfaatkan internet dalam kegiatan bisnis relatif seimbang. Sebesar 55 persen responden memiliki niat positif untuk memanfaatkan internet dalam kegiatan bisnis dan 45 persen responden memiliki intensi negatif untuk memanfaatkan internet. Data ini menunjukkan bahwa sikap responden yang positif terhadap pemanfaatan internet dalam kegiatan bisnis belum tentu akan diikuti dengan intensi yang positif pula dalam pemanfaatannya. Kemungkinan hal ini disebabkan oleh berbagai kendala teknis yang dihadapi responden, seperti penguasaan teknologi informasi, ketersediaan sarana, dan lain-lain.

\section{Hubungan antara Sikap dengan Intensi Pemanfaatan Internet dalam Kegiatan Bisnis}

Sebagaimana diungkapkan oleh Azwar (1998), intensi merupakan fungsi dari dua determinan dasar, yaitu sikap individu terhadap perilaku (aspek personal) dan persepsi individu terhadap tekanan sosial untuk melakukan atau tidak melakukan perilaku yang bersangkutan yang disebut dengan norma subjektif.

Bila dianalisis dengan menggunakan korelasi Pearson Product Moment antara sikap dengan intensi pemanfaatan internet diperoleh nilai Sig. (1-tailed $)=0,000$. Artinya, terdapat hubungan antara sikap dengan pemanfaatan internet dalam kegiatan bisnis dengan nilai $r=0,827$ yang menunjukkan hubungan yang tinggi atau kuat. Berdasarkan data tersebut terbukti bahwa jika sikap terhadap pemanfaatan internet dalam kegiatan bisnis adalah positif, maka intensinya akan positif pula. Begitu juga sebaliknya, sikap yang negatif terhadap pemanfaatan internet dalam kegiatan bisnis akan menghasilkan intensi yang negatif.

Tabel9. Persentase Sikap dan Intensi Pemanflatatan Internet dalam Kegiatan Bisnis

\begin{tabular}{|c|c|c|c|c|c|c|c|c|c|c|c|c|c|c|c|}
\hline \multirow{4}{*}{ Intersis } & \multicolumn{15}{|c|}{ Slikap } \\
\hline & \multicolumn{4}{|c|}{ Kogniliff } & \multicolumn{4}{|c|}{ Afektif } & \multicolumn{3}{|c|}{ Konatiff } & \multicolumn{4}{|c|}{ Total } \\
\hline & $\overline{P_{0}}$ & itff & Neg & & $\mathrm{PO}$ & & & atif & Posit & & Negati & & ositif & & legatif \\
\hline & n & $\%$ & n & $\%$ & n & $\%$ & n & $\%$ & n & $\%$ & n & & $\%$ & n & $\%$ \\
\hline Positif & 15 & 37,5 & 7 & 17,5 & 20 & 50 & 2 & 5 & 18 & 15 & 1 & 020 & 50 & 5 & 12,5 \\
\hline Negatiff & 8 & 20 & 10 & 25 & 3 & 7,5 & 15 & 37,5 & 8 & 0 & 0 & 52 & 5 & 13 & 32,5 \\
\hline Total & 23 & 57,5 & 17 & 22,5 & 23 & 57,5 & 17 & 42,5 & 26 & $\overline{65}$ & 4 & & & 18 & 45 \\
\hline
\end{tabular}

\section{Hubungan antara Norma Subyektif dengan Intensi Pemanfaatan Internet dalam Kegiatan Bisnis}

Norma subjektif merupakan salah satu komponen yang dapat membentuk sikap menurut Theory of Reasoned Actions. Hasil tabulasi silang antara intensi terhadap pemanfaatan internet dalam kegiatan bisnis dengan norma subjektif dapat dilihat pada Tabel 10 .

\begin{tabular}{|c|c|c|c|c|c|c|}
\hline \multirow{3}{*}{ Intensl } & \multicolumn{4}{|c|}{ Norma Subjektif } & \multirow{3}{*}{ Total } & \multirow{3}{*}{$\%$} \\
\hline & \multicolumn{2}{|c|}{ Positifif } & \multicolumn{2}{|c|}{ Negatif } & & \\
\hline & n & $\%$ & n & $\%$ & & \\
\hline \begin{tabular}{|l|} 
Positiff \\
\end{tabular} & 20 & 50 & 2 & 5 & 22 & 55 \\
\hline \begin{tabular}{|l|} 
Negatiff \\
\end{tabular} & 10 & 25 & 8 & 20 & 18 & 45 \\
\hline \begin{tabular}{|l|} 
Total \\
\end{tabular} & 30 & 75 & 10 & 25 & 40 & 100 \\
\hline
\end{tabular}

Bila dianalisis dengan menggunakan korelasi Pearson Product Moment antara norma subjektif dengan intensi pemanfaatan internet dalam kegiatan bisnis diperoleh nilai Sig.(1-tailed) sebesar 0,003 atau lebih kecil dari $\alpha(0,05)$. Artinya, terdapat hubungan yang signifikan antara norma subjektif dengan intensi terhadap pemanfaatan internet dalam kegiatan bisnis dengan nilai $r=0,421$. Terbukti bahwa jika keyakinan individu mengenai kemungkinan orang lain di sekitarnya menyetujui dan mendukung untuk memanfaatkan internet dalam kegiatan bisnis positif, maka intensi atau niat untuk memanfaatkan internet dalam kegiatan bisnis juga positif, bergitu pula sebaliknya.

\section{Pengaruh Sikap dan Norma Subjektif terhadap Intensi Pemanfaatan Internet dalam Kegiatan Bisnis}

Pengaruh sikap dan norma subjektif terhadap intensi pemanfaatan internet dilihat dari nilai t. Apabila t-hitung $>\mathrm{t}$-tabel, maka terdapat pengaruh yang signifikan. Hasil uji regresi antara sikap dengan intensi memiliki nilai thitung=8,146 atau lebih besar dari ttabel $(2,021)$, maka sikap berpengaruh signifikan terhadap intensi pemanfaatan internet dalam kegiatan bisnis. Hasil uji regresi antara norma subjektif dengan intensi memiliki nilai t-hitung=1,630 atau lebih kecil dari t-tabel $(2,021)$, maka norma subjektif tidak memiliki pengaruh yang 
signifikan terhadap intensi pemanfaatan internet dalam kegiatan bisnis.

Hasil uji regresi antara sikap dan norma subjektif terhadap intensi pemanfaatan internet dalam kegiatan bisnis menunjukkan nilai konstanta (B) atau total skor intensi adalah 1,172 jika skor X1 (sikap) dan X2 (norma subjektif) $=0$. Nilai koefisien X1(B) adalah sebesar 0,287, artinya untuk setiap kenaikan satu skor variabel sikap akan meningkatkan skor intensi sebesar 0,287. Nilai koefisien X2(B) adalah sebesar 0,156, artinya untuk setiap kenaikan satu skor variabel norma subjektif akan meningkatkan skor intensi sebesar 0,156. Persamaan untuk intensi adalah $\mathrm{Y}=1,172+0,287 \mathrm{X} 1+0,156 \mathrm{X} 2$.

Intensi dipengaruhi oleh sikap terhadap pemanfaatan internet. Semakin kuat sikap positif pada pengusaha UKM terhadap pemanfaatan internet, maka semakin kuat pula intensi atau niat untuk memanfaatkan internet dalam kegiatan bisnis. Begitu pula semakin besar kepercayaan pengusaha UKM bahwa lingkungannya mendukung untuk memanfaatkan internet dalam kegiatan bisnis, maka semakin besar pula intensi atau niat untuk memanfaatkan internet dalam kegiatan bisnis.

Pengaruh sikap terhadap pemanfaatan internet pada intensi ternyata lebih besar dan signifikan dibandingkan dengan pengaruh norma subjektif terhadap intensi. Sikap positif berupa kepercayaan dan keyakinan bahwa internet dapat membantu pengusaha UKM dalam kegiatan bisnisnya, ketertarikan dan kecenderungan untuk memanfaatkan internet mempengaruhi niat pengusaha UKM untuk memanfaatkan internet sehingga mendukung kegiatan bisnisnya. Namun, keyakinan yang besar bahwa orang-orang di lingkungan pengusaha akan mendukungnya untuk memafaatkan internet bagi kegiatan bisnis belum tentu akan membuat pengusaha UKM memiliki niat yang besar untuk memanfaatkan internet dalam kegiatan bisnis. Dalam penelitian ini norma subjektif tidak menunjukkan pengaruh yang signifikan terhadap intensi pemanfaatan internet.

\section{KESIMPULAN DAN SARAN}

\section{Kesimpulan}

Sebagian besar responden memiliki sikap yang positif terhadap pemanfaatan internet dalam kegiatan bisnis, baik dilihat dari komponen kognitif, afektif maupun konatifnya. Sebagian besar responden juga memiliki norma subjektif yang positif. Hal ini menandakan bahwa ada keyakinan dari individu bahwa lingkungannya mendukung untuk memanfaatkan internet dalam kegiatan bisnis. Sebagian besar responden juga memiliki intensi yang positif. Intensi yang positif ditandai dengan adanya niat dari pengusaha UKM untuk memanfaatkan dan mengoptimalkan pemanfaatan internet untuk menunjang kegiatan bisnisnya.

Sikap terhadap pemanfaatan internet dalam kegiatan bisnis terbukti memiliki hubungan dan pengaruh yang signifikan pada intensi pemanfaatan internet. Semakin positif sikap pengusaha UKM, maka semakin kuat pula intensi atau niat untuk memanfaatkan internet dalam kegiatan bisnis. Semakin tinggi pengetahuan, keyakinan mengenai pemanfaatan internet dalam kegiatan bisnis, ketertarikan dan kecenderungan untuk memanfaatkan internet, maka semakin besar pula niat pengusaha UKM untuk memanfaatkan internet dalam kegiatan bisnisnya. Norma subjektif terbukti memiliki hubungan dengan intensi pemanfaatan internet, namun tidak berpengaruh signifikan terhadap intensi pemanfaatan internet dalam kegiatan bisnis. Keyakinan yang besar bahwa orang-orang di lingkungan pengusaha akan mendukungnya untuk memafaatkan internet bagi kegiatan bisnis belum tentu beperngaruh pada pengusaha UKM memiliki niat yang besar untuk memanfaatkan internet dalam kegiatan bisnis.

\section{Saran}

1. Sikap dan intensi yang positif terhadap pemanfaatan internet dalam kegiatan bisnis hendaknya dijadikan sebagai peluang baik bagi pengusaha UKM, masyarakat maupun pemerintah, untuk mengoptimalkan penggunaan internet sebagai salah satu cara pengembangan kegiatan bisnis terutama sebagai sarana promosi dan perluasan jaringan usaha.

2. Perlu adanya perhatian dari pemerintah maupun lembaga pendamping UKM untuk mendampingi dan memberikan pelatihan mengenai pemanfaatan internet dalam kegiatan bisnis dalam upaya membantu meningkatkan daya saing dan potensi bisnis di masa yang akan datang.

\section{DAFTAR PUSTAKA}

Alma, Buchari. 2003. Kewirausahaan. Alfabeta. Bandung. Anonim. 2009. http://nusantaranews.wordpress.com/2009/02/28/d aftar-jumlah-penggunainternet-dunia-1995-2008/ (diakses pada 15 Oktober 2009).

Azwar, Saifuddin. 1998. Sikap Manusia dan Pengukurannya. Pustaka Pelajar. Yogyakarta.

Baron, Robert A dan Donn Byrne. 2003. Psikologi Sosial Jilid 1. Erlangga. Jakarta.

Purwanto, Djoko. 2003. Komunikasi Bisnis. Erlangga. Jakarta.

Rakhmat, Jalaluddin. 2008. Psikologi Komunikasi. PT. Remaja Rosdakarya. Bandung.

Riyanti, Benedicta Prihatin Dwi. 2003. Kewirausahaan Dari Sudut Pandang Psikologi Kepribadian. Grasindo. Jakarta.

Saputro, Dani Sudibyo. 2009. Analisis Karakteristik Wirausaha Peternak Kambing Perah di Kabupaten Bogor Jawa Barat. Skripsi. Fakultas Ekonomi Manajemen Institut Pertanian Bogor.

Sarwono, Sarlito Wirawan. 1999. Psikologi Sosial (Individu dan Teori-Teori Psikologi Sosial). Balai Pustaka. Jakarta.

Singarimbun, Masri dan Sofian Effendy. 1989. Metode Penelitian Survai. LP3ES. Jakarta.

Sujanto, Agus, Halem Lubis dan Taufik Hadi. 2004. Psikologi Kepribadian. PT. Bumi Aksara. Jakarta. 
Wahyuni, E.S. 2004. Pedoman Teknis Menulis Skripsi. Penerbit Jurusan Ilmu Sosial Ekonomi Fakultas Pertanian Bogor Institut Pertanian Bogor. Grafika Mardi Yuana. Bogor. 